\title{
The chief executive officer pay-performance relationship within South African state-owned entities
}

\begin{tabular}{|c|c|}
\hline \multicolumn{2}{|c|}{$\begin{array}{l}\text { Authors: } \\
\text { Magda L. Bezuidenhout }{ }^{1} \text { (D) } \\
\text { Mark H.R. Bussin }^{2} \\
\text { Mariette Coetzee }^{1}\end{array}$} \\
\hline \multicolumn{2}{|c|}{$\begin{array}{l}\text { Affiliations: } \\
{ }^{1} \text { Department of Human } \\
\text { Resource Management, } \\
\text { University of South Africa, } \\
\text { South Africa }\end{array}$} \\
\hline \multicolumn{2}{|c|}{$\begin{array}{l}{ }^{2} \text { Department of Industrial } \\
\text { Psychology and People } \\
\text { Management, University of } \\
\text { Johannesburg, South Africa }\end{array}$} \\
\hline \multicolumn{2}{|c|}{$\begin{array}{l}\text { Corresponding author: } \\
\text { Magda Bezuidenhout, } \\
\text { bezuiml@unisa.ac.za }\end{array}$} \\
\hline \multicolumn{2}{|c|}{$\begin{array}{l}\text { Dates: } \\
\text { Received: } 31 \text { July } 2017 \\
\text { Accepted: } 12 \text { Feb. } 2018 \\
\text { Published: } 14 \text { May } 2018\end{array}$} \\
\hline \multicolumn{2}{|c|}{$\begin{array}{l}\text { How to cite this article: } \\
\text { Bezuidenhout, M.L., Bussin, } \\
\text { M.H.R., \& Coetzee, M. } \\
\text { (2018). The chief executive } \\
\text { officer pay-performance } \\
\text { relationship within } \\
\text { South African state-owned } \\
\text { entities. SA Journal } \\
\text { of Human Resource } \\
\text { Management/SA Tydskrif vir } \\
\text { Menslikehulpbronbestuur, } \\
\text { 16(0), a983. https://doi. } \\
\text { org/10.4102/sajhrm. } \\
\text { v16i0.983 }\end{array}$} \\
\hline \multicolumn{2}{|c|}{$\begin{array}{l}\text { Copyright: } \\
\text { (C) 2018. The Authors. } \\
\text { Licensee: AOSIS. This } \\
\text { is licensed under the } \\
\text { Creative Commons } \\
\text { Attribution License. }\end{array}$} \\
\hline \multicolumn{2}{|l|}{ Read online: } \\
\hline 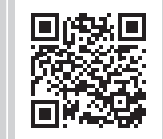 & $\begin{array}{l}\text { Scan this QR } \\
\text { code with your } \\
\text { smart phone or } \\
\text { mobile device } \\
\text { to read online. }\end{array}$ \\
\hline
\end{tabular}

Orientation: Over the years, the increase in executive remuneration in state-owned entities (SOEs) has been the subject of intense discussions. The poor performance of some SOEs with highly remunerated executives begs the question of whether chief executive officers in South African SOEs deserve the high levels of remuneration they receive.

Research purpose: This study examined the relationship between chief executive remuneration and several measures of company performance across Schedule 2 SOEs within South Africa.

Motivation for the study: Notwithstanding the widely publicised poor performance of South African SOEs, their importance and relevance remains evident. Regrettably, the literature on what fundamentally drives their performance is lacking.

Research design, approach and method: This quantitative, longitudinal study, conducted over a 9-year period, collected secondary data from the annual reports of 18 Schedule 2 SOEs. The primary statistical technique used in the study was ordinary least square (OLS) multiple regression analysis on a pooled dataset. Chief executive remuneration consisted of fixed salary and total remuneration.

Main findings: A relationship was found between chief executive remuneration and company performance, although mainly an inverse relationship.

Practical and managerial implications: The improved understanding and knowledge of the relationship between chief executive remuneration and SOE performance may be used by the organisation and HR practitioners to direct and inform strategies for organisational effectiveness and business excellence.

Contribution or value-add: This research provides new knowledge to the limited research available on SOEs in South Africa. Further, it reveals an unexplored area of potential research, that is, the importance of irregular, fruitless and wasteful expenditure as a performance measure in SOEs.

\section{Introduction}

\section{Key focus of the study}

Questions such as 'Are South African executives' packages linked to performance?' come to mind when reading various newspapers, as well as academic and business articles. Concerns regarding excessive remuneration packages of chief executive officers (CEOs) have been added to an ongoing concern about the widening gap between the remuneration of executives and ordinary employees, as well as their large termination payments with a perceived lack of justification (Theunissen, 2010).

The focus of this study was Schedule 2 state-owned entities (SOEs) in South Africa. State-owned entities play a vital role in the economies of many countries, and the outrage over what many consider to be excessive CEO remuneration warrants research and plays an important role throughout South Africa (Corporate Governance of State-Owned Enterprises in Africa, 2009). Despite the highly publicised incompetence and poor performance of some SOEs, convincing evidence proposes that SOEs remain relevant (Boko \& Yuan Jian, 2011; Mbo \& Adjasi, 2017).

Crafford (2012) postulates that various stakeholders hold diverse views regarding how SOEs should benchmark their remuneration. State-owned entities have mostly ignored the remuneration guidelines of the Department of Public Enterprises (DPE), which insists that they need to be 
benchmarked against the private sector (Crafford, 2012). In 2011, a new guideline was established, intended to serve as an improvement on the 2007 guideline. However, not all South African SOEs adopted and implemented the guidelines (Maloa \& Bussin, 2016, p. 10).

\section{Background to the study}

The link between pay and performance has for some time now come under increased scrutiny, from the media and the public as well as from an academic perspective, that excessive remuneration is not aligned with SOE performance (21st Century Pay Solutions, 2012). Two cases in point follow, the first being the R9467 million total remuneration (TR) that Brian Molefe - Eskom's former acting CEO - received during the 2015/2016 financial year (Peyper, 2016). The TR packages that Eskom executives received during the 2015/2016 financial year amounted to $R 75.33 \mathrm{~m}$, compared to the R50.61m paid in the previous financial year (Peyper, 2016). Second, South African Airways' (SAA) former suspended CEO, Monwabisi Kalawe, received almost R2.7m after his resignation (Majangaza, 2015).

Over and above the millions of rands paid out to SOE CEOs, government has had to 'bail out' a number of SOEs over the years to keep them afloat. For example, during 2015, Eskom received a R23 billion bailout from government (Fripp, 2015). South African Airways has been surviving on stateguaranteed loans for the past few years. In addition, SAA posted a loss of R1.5bn in the 2015/2016 financial year (Gerber, 2016). During 2017, the South African government announced that SAA will receive an undisclosed sum from the National Revenue Fund in order to pay back loans of approximately R2.3bn to Standard Chartered Bank (Rothpletz, 2017). Rothpletz (2017) reports that SAA, in total, has borrowed R19bn from government.

State-owned entities, unlike private companies, receive the larger part of their revenue from the National Treasury (who collects from the taxpayer) and are supposed to serve the public. However, the remuneration of top executives in SOEs seems to be competing with that of private companies. Consequently, consumers pay high tariffs for the products and services of SOEs such as Eskom, while consumers should be benefiting from the funding paid to Eskom by South Africa's National Treasury (Ngwenya \& Khumalo, 2012). In addition, the remuneration of CEOs of SOEs is of special importance to sustainable public service provision (Ngwenya \& Khumalo, 2012; Papenfuss \& Schmidt, 2016).

\section{Research purpose}

The focus of this study was on Schedule 2 SOEs in South Africa. Taking into consideration the important role that SOEs play in the economic prosperity of a country, the outrage over what many consider to be excessive CEO remuneration warrants research. The main problem, which informed the present study, is therefore the excessive remuneration packages that CEOs in SOEs receive, despite poor performance, and government 'bail out' of some of these SOEs.

\section{Trends from the research literature}

From past research on executive remuneration and company performance, there seems to be no real consensus on the relationship between executive remuneration and company performance. This is partially because of the diverse set of disciplines involved in these studies and the wide variety of methods used to investigate the questions (Florin, Hallock \& Webber, 2010). In addition, for the private sector there are numerous studies in scientific journals on the level, design and determinants of executive directors' remuneration (Bussin \& Nel, 2015; Jensen \& Murphy, 2004; Jeppson, Smith \& Stone, 2009; Ngwenya \& Khumalo, 2012). However, with regard to studies on SOEs, the literature reports on very few empirical studies (Papenfuss \& Schmidt, 2016).

\section{Research objectives}

The primary research objective was to determine whether there is a relationship between CEO remuneration and SOEs' performance over a 9-year period (2006-2014). Further, in view of the importance and the important role SOEs play, it becomes important to understand the measures that drive their performance. However, this remains a poorly researched area in organisational science (Mbo \& Adjasi, 2017). The secondary research objectives were to determine the following:

- the relationship between $\mathrm{CEOs}^{\prime}$ fixed pay (FP) and the SOEs' performance

- the relationship between CEOs' TR and the SOEs' performance.

\section{Potential value-add of the study}

This study contributes to the knowledge on the relationship between CEO remuneration and the performance of Schedule 2 SOEs in South Africa. In addition, there is insufficient understanding of what combination of variables positively influences SOE performance (Mbo \& Adjasi, 2017). This research therefore sought to contribute to an enhanced understanding in this respect. This research will be of particular interest to investors and other stakeholders, such as unions and regulators, who expect CEOs' remuneration to be aligned with the SOEs' performance. A contemporary statistical package, named EViews, was used in analysing the data. EViews is specifically designed to analyse longitudinal panel data, unlike the traditional SPSS, which is not specifically designed for this set of data.

A more detailed review of the literature follows in the next section. The research design section outlines the longitudinal, quantitative, archival research method selected and describes the statistical analysis employed. The results of the study are then presented and discussed. The article concludes with a brief discussion of the research limitations and practical implications for remuneration practitioners. 


\section{Literature review}

\section{Chief executive officer remuneration constructs}

Executive remuneration refers to the FP, short-term incentives and long-term incentives (LTIs), and related benefits awarded to those who occupy the most senior decision-making positions in private and public-sector enterprises (Bussin, 2011). The design of remuneration schemes is a key factor that affects the behaviour and awareness for acting in accordance with the overriding aims of the public authority. Moreover, pay seems key in attracting, recruiting and retaining executives in the public management environment. This is especially true where executives need to be recruited from the private sector (Jerry, Pan \& Tian, 2011; Ngwenya \& Khumalo, 2012; Papenfuss \& Schmidt, 2016). Walker (2010) concurs with this notion and postulates that companies can attract the best executives by providing a competitive remuneration package.

For the purpose of this article, the focus is on FP and TR. These can be defined as follows:

- FP/salary: it is the guaranteed base pay that executives receive. This is normally a risk-free monthly payment (Ellig, 2007).

- TR: it includes FP plus short-term incentives (21st Century Pay Solutions, 2010). This component is also known as the total cost of employment.

Attractive CEO remuneration packages are created to ensure that the company is able to attract and retain the best possible CEOs (Bussin \& Modau, 2015). In their study, Maloa and Bussin (2016) found that attractive remuneration packages are determined to a large extent by the size of the organisation, type of industry and job function.

\section{Organisational performance measures}

Researchers generally use financial performance as a measure of company performance (Demirer \& Yuan, 2013). Numerous studies have used accounting-based measures, such as net profit (NP), return on equity (ROE) and return on assets (ROA), together with market-based measures, such as stock price and total shareholder return, as measures of company performance (Nourayi \& Mintz, 2008). Papenfuss and Schmidt (2016) posit that 9 out of 11 studies on SOEs used financial performance ratios (measures by accounting and/or stock return) to examine the pay-performance relationship. Nearly all studies of SOEs used financial figures to examine associations between company performance and the level of CEO remuneration, for example, Otieno (2011), Minhat and Abdullah (2014), He, Conyon and Shaw (2013), Ngwenya and Khumalo (2012) and Mbo and Adjasi (2014). However, despite the numerous studies, there seems to be limited consensus on the optimal measure of company performance (Bussin \& Modau, 2015).

\section{The link between chief executive officer remuneration and company performance}

Pay-performance sensitivity refers to the relationship between remuneration outcomes and measures of company performance, with not one conclusive measure but rather a broad set of variables (Bussin, 2015). Several research studies have shown the diverse nature and contrasting results of the study. With regard to the private sector, many South African empirical studies (i.e. Bradley, 2011; Bussin \& Blair, 2015; Bussin \& Modau, 2015; Scholtz \& Smit, 2012; Theku, 2014) and international empirical studies (inter alia, Gigliotti, 2012; Murphy, 1985; Otieno, 2011; Tariq, 2010; Tian, 2013) have investigated the pay-performance relationship of CEO remuneration. The majority of these scientific studies did not provide evidence of a concrete pay-performance relationship with regard to the private sector.

As opposed to studies that focused on the private sector, there are very few empirical studies for SOEs regarding the relationship between CEO remuneration and company performance. In fact, Maloa and Bussin (2016) concluded that the literature in scientific journals on the subject of the investigation of executive remuneration in South African SOEs is limited. International studies, such as Minhat and Abdullah (2014), He et al. (2013), Jerry et al. (2011) as well as Kato and Long (2006), considered listed SOEs from the national government level of Asian countries. From a South African perspective, studies conducted on SOEs include Otieno (2011), Ngwenya and Khumalo (2012) and Maloa (2015). However, Maloa's study focused on the transformation as an element of executive remuneration in South African SOEs. Interestingly, Mbo and Adjasi (2017) argue that a developing view could be that SOEs do perform well depending on the variables used to measure performance.

A number of researchers concluded that there is a positive relationship between CEO remuneration and company performance (Dai, 2014; Demirer \& Yuan, 2013; Jensen \& Murphy, 1990; Murphy, 1985; Ozkan, 2011; Zigler, 2011). The bulk of these studies were conducted in the UK and the USA. Studies conducted on SOEs, and where a positive relationship was found between CEO remuneration and company performance, are those reported by Xin and Tan (2009) and Chen, Ezzamel and Cai (2011). Otieno (2011) and Ngwenya and Khumalo (2012) conducted studies on South African SOEs. Otieno (2011), aimed to determine the relationship between financial performance and executive remuneration in South African SOEs within the context of the agency theory. Otieno's (2011) findings revealed a positive relationship between executive remuneration and company performance. Ngwenya and Khumalo (2012) found a positive relationship between CEO remuneration (base salary) and the size of SOEs as measured by total revenue and number of employees.

In a Brazilian study conducted by Krauter and De Sousa (2013) during the period 2006-2007, no significant relationship was found between executive remuneration and corporate financial performance of sales growth and ROE. In South Africa, Bussin and $\mathrm{Nel}$ (2015) found a negative relationship between ROE and the guaranteed cost to company of the CEOs in the South African retail and consumer goods sector. Supporting this evidence, Kyalo (2015) found a weak negative relationship between executive remuneration and financial performance. 
Minhat and Abdullah (2014) found no evidence of a payperformance relationship in listed Chinese SOEs. Ngwenya and Khumalo (2012) found no positive relationship between CEO remuneration and SOE performance in South Africa (measured with ROA). In another South African study, Bradley (2013) investigated the relationship between CEO remuneration and company performance in the 40 largest public companies listed on the Johannesburg Stock Exchange for a 5-year period. Bradley (2013) found no relationship between CEO remuneration and measures of performance such as ROE, ROA, and earnings per share. Osei-Bonsu and Lutta (2016) examined the effectiveness of using CEO cash remuneration schemes in improving company performance in emerging markets. Osei-Bonsu and Lutta (2016) found no significant relationship between cash remuneration and ROA or ROE. Papenfuss and Schmidt (2016) examined the payperformance relationship of executive directors from 176 SOEs in 11 sectors. They found no significant link between financial performance ratios (ROA and ROE) and the remuneration of executive directors.

It is evident that research conducted to establish the link between CEO remuneration and company performance metrics is inconclusive and that the results vary depending on the country, industry sector and the selected performance measures that were investigated (Bussin \& Blair, 2015). Furthermore, the extent to which previous studies can aid the understanding of company performance in the context of SOEs remains a relatively unexplored area.

\section{Research design \\ Research approach}

The research approach decided upon was a longitudinal, empirical quantitative study aimed at assessing the relationship between CEO remuneration and measures of company performance. This research was further a desktop study, archival in nature, using secondary data gathered from annual reports.

\section{Research method \\ Research participants}

The research data utilised were obtained from Schedule 2 SOEs in South Africa for the period 2006-2014. The combined number of Schedule 2 SOEs were 21 as per the Department of National Treasury as on 30 April 2015 (see Table 1). The reason for using Schedule 2 SOEs for the purposes of this study was because these SOEs were (1) financially and operationally independent, (2) able to operate according to ordinary business principles and (3) self-funded (Public Financial Management Act, 1999). The number of Schedule 2 SOEs, the number of company performance measures used and the 9-year period (a large enough period) were seen as being sufficient for the research.

Because of the small target population, a sampling methodology was not employed and the entire population
TABLE 1: Schedule 2 public entities as at 30 April 2015.

\begin{tabular}{|c|c|}
\hline Number & Public entity \\
\hline 1 & Air Traffic and Navigation Services Company Limited \\
\hline 2 & Airports Company of South Africa Limited \\
\hline 3 & Alexkor Limited \\
\hline 4 & Armaments Corporation of South Africa Limited \\
\hline 5 & Broadband Infrastructure Company (Pty) Ltd \\
\hline 6 & CEF (Pty) Ltd \\
\hline 7 & DENEL (Pty) Ltd \\
\hline 8 & Development Bank of Southern Africa \\
\hline 9 & Eskom \\
\hline 10 & Independent Development Trust \\
\hline 11 & Industrial Development Corporation of South Africa Limited \\
\hline 12 & Land and Agricultural Development Bank of South Africa \\
\hline 13 & South African Airways (Pty) Ltd \\
\hline 14 & South African Broadcasting Corporation Limited \\
\hline 15 & South African Express (Pty) Ltd \\
\hline 16 & South African Forestry Company Limited \\
\hline 17 & South African Nuclear Energy Corporation Limited \\
\hline 18 & South African Post Office Limited \\
\hline 19 & Telkom SA Limited \\
\hline 20 & Trans-Caledon Tunnel Authority \\
\hline 21 & Transnet Limited \\
\hline
\end{tabular}

Source: National Treasury. (2015). Public institutions listed in PFMA schedule 1, 2, 3A, 3B, 3C and $3 D, 30$ April 2015, from http://www.treasury.gov.za/legislation/pfma/public $\% 20$ entities/2015-04-30\%20Public\%20institutions\%20Sch\%201-3D.pdf

of 21 SOEs was used in the study. These 21 SOEs were subjected to the following criteria for inclusion in the study:

- The annual reports had to be available on either the McGregor BFA database or the SOE's website.

- SOEs had to have a 9-year financial history, which had to include the CEOs' remuneration.

After implementing the selection criteria, 18 of the 21 Schedule 2 SOEs were included in the study.

\section{Measuring variables}

The dependent variables for this study were the various components of CEO remuneration such as FP and TR. In studies with the aim of determining the relationship between CEO remuneration and the financial performance of an organisation, it would be ideal to include LTIs (Lippert \& Porter, 1997; Murphy, 1985). Yet, as Bussin and Modau (2015) concluded, measuring LTIs has proven to be difficult and uncertain. Long-term incentives are based on future performance targets only by the time TR is awarded. It has therefore become standard practice to omit LTIs in analysing pay-performance relationships (Bussin \& Modau, 2015). In addition, SOEs are not listed on the Johannesburg Stock Exchange and only a few SOEs provide LTI schemes.

The independent variables considered were the financial performances of the SOEs. This research approached the analyses of company performance from an organisational theory perspective, borrowing from research conducted by the DPE on variables known to drive SOE performance under its jurisdiction. The performance measures used in the study included the following: 
- Turnover is the money generated by a company through its business activities during a specific period.

- Operating profit/loss (also termed operating income) is the profit/loss from a company's regular primary business operations. It is an indicator of the profitability of a company's basic business activities and displays the relationship between revenue earned and expenses incurred in producing this revenue (Williams, Haka, Bettner \& Carcello, 2006).

- NP/loss (also termed net income) represents the overall increase (or decrease) in owners' equity from all profitdirected activities during a period. This measurement offers an indication of management's proficiency in controlling expenses and retaining a realistic share of its revenue as profit (Williams et al., 2006).

- Liquidity ratio (LR) is a company's ability to pay its short-term liabilities with its current assets (Williams et al., 2006). Literature suggests that company liquidity is a critical resource in influencing performance in the context of a generic enterprise (see Mbo \& Adjasi, 2017).

- Solvency ratio is the ratio between the total liabilities of a business and its total assets. It is a measure of solvency and of a creditor's long-term risk.

- Return on capital employed (ROCE) is a financial ratio that measures a company's profitability and the effectiveness with which its capital is employed. Return on capital employed is particularly useful for comparing the performance of companies in capital-intensive sectors such as utilities and telecoms.

- Return on equity is the amount of net income returned as a percentage of shareholders equity (Bussin \& Modau, 2015). Papenfuss and Schmidt (2016) posit that ROE is commonly used as a financial goal/criteria for SOEs as well as in day-to-day operations.

- Audit opinion $(A O)$ is a certification of financial statements prepared by an independent auditor. The auditor's opinion will set out the scope of the audit and the auditor's opinion of the procedures and records used to generate the financial statements. An AO is a good indication of how responsibly the SOE applies accounting and financial controls. No previous studies included the $\mathrm{AO}$ as a company performance measure. Audit opinion was tested using dummy variables, because of its categorical nature, with $A O 3$ (Adverse opinion) being the reference category.

- Irregular, fruitless and wasteful expenditure (IFWE) is an expenditure made in vain, which could have been avoided had reasonable care been exercised. In most part, such expenditure is incurred because of non-compliance with legislation (Auditor-General South Africa, 2012). For the purpose of this research, total IFWE was used. Table 2 shows how each of the independent variables were calculated and recorded.

TABLE 2: Measurement of independent variables.

\begin{tabular}{|c|c|c|}
\hline Variable & Measures & Unit of measurement \\
\hline Turnover (T) & Turnover $=$ Revenue & $\begin{array}{l}\text { South African rand; financial } \\
\text { item stated in the annual report }\end{array}$ \\
\hline Operating profit/loss (OP) & Operating profit $=$ operating income $=$ Gross profit $=$ Profit before tax & $\begin{array}{l}\text { South African rand; financial } \\
\text { item stated in the annual report }\end{array}$ \\
\hline Net profit/loss (NP) & Net Profit/loss $=$ Profit/loss after tax & $\begin{array}{l}\text { South African rand; financial } \\
\text { item stated in the annual report }\end{array}$ \\
\hline Liquidity (LR) & $\frac{\text { Current assets }}{\text { Current liabilities }}$ & Ratio \\
\hline Solvency (SR) & $\frac{\text { Total assets }}{\text { Total liabilities }}$ & Ratio \\
\hline $\begin{array}{l}\text { Return on capital } \\
\text { employed (ROCE) }\end{array}$ & $\frac{\text { Operating profit (income) }}{\text { Capital employed }}$ & Ratio \\
\hline Return on equity (ROE) & $\frac{\text { Net profit after tax }}{\text { Total equity }}$ & Ratio \\
\hline $\begin{array}{l}\text { Irregular, fruitless and } \\
\text { wasteful expenditure } \\
\text { (IFWE) }\end{array}$ & $\begin{array}{l}\text { Classified into three categories (South African Qualifications Authority, 2013): } \\
\text { Irregular expenditure, as defined by the Public Financial Management Act (PFMA), means expenditure, other than } \\
\text { unauthorised expenditure, that is incurred in contravention of, or not in accordance with, any applicable legislation } \\
\text { (not just the PFMA). } \\
\text { Unauthorised expenditure is the overspending on an approved budget spending not in line with the original } \\
\text { approved budget item, or expenditure without the appropriate approval. } \\
\text { Fruitless and wasteful expenditure, as defined in the PFMA, is expenditure that was made in vain and could have } \\
\text { been avoided had reasonable care been implemented. Such expenditure may be of an operational or a capital nature. }\end{array}$ & $\begin{array}{l}\text { South African rand and actual } \\
\text { figures were captured as } \\
\text { reported in the annual reports }\end{array}$ \\
\hline
\end{tabular}




\section{Research procedure}

The relationship between the CEO remuneration and measures of company performance were observed over a period of 9 years (2006-2014.) The 9-year period was considered adequate to ensure limited influence of shortterm irregularities, while being short enough to provide reliable estimates of the research concepts (Bussin \& Modau, 2015). The researchers sourced data from annual financial statements in the annual reports of the SOEs under study. Using secondary data ensured that the data was readily available and would be of a higher quality than primary data because of the data being reported in a standardised manner, rather than for a particular objective (Otieno, 2011; Swatdikun, 2013).

The remuneration and financial data used were reflected as at 31 March of each year (the financial year-end of the SOEs). In calculating FP and TR, CEO turnover was taken into account because CEOs changed during some financial years. Chief executive officer remuneration values may therefore not have been in respect of a full financial year (01 April-31 March) or of their functions as CEO. Of the 162 (18 SOEs, 9 years) panel observations, there were 36 cases where CEO positions changed. To compensate for these changes, the researchers included the information of the CEO who had been in the position for the longest time during the financial year. In order to (1) not exclude these observations from the sample, and because the calculations involved were straightforward and (2) for remuneration data not to be misrepresented, the researchers annualised the remuneration to reflect a full year's remuneration. There were 36 cases where the researchers annualised CEO remuneration (FP and benefits). Baptista (2010) applied the same methodology.

In six cases the remuneration of the acting CEOs was used. In these cases the unadjusted CEO remuneration data were employed. There were also three cases where termination payments were included in the FP portion of the package. In order to not distort the remuneration data, the researchers used FP of the previous year and a percentage package increase calculated for that year. In each of these three cases, the researchers applied the expected salary increase provided in the relevant SOEs' annual reports. This method prevented a misrepresentation of the CEO remuneration data, as the remuneration values calculated were in line with the rest of the CEO remuneration data collected for the SOEs (previous and subsequent years).

\section{Statistical analysis}

Data were analysed using SPSS (Version 22, for the descriptive analysis) and EViews (Version 8) to determine the relationship between CEO remuneration and SOE performance. Polakow (2015) raised concerns regarding the use of standard statistical techniques in financial analysis that ignore autocorrelation and stationarity. By using EViews, which accommodates panel data and provides the necessary econometric analysis required for this type of data, this research addressed Polakow's (2015, p. 53) concern, which contributes to 'broad market inefficiency'.

The dataset consisted of a panel of 162 observations (18 SOEs $\times 9$ years). Chief executive officer remuneration and company performance components were tested for normality, stationarity (using the augmented Dickey-Fuller test) and autocorrelation (using the Durbin-Watson [DW] test). The results of the assumption testing were taken into account in the analysis conducted by choosing the appropriate estimation method.

Further, the tolerance and variance inflation factor (VIF) information in the regression models was used to test for the presence of multicollinearity. Multicollinearity occurs when two explanatory variables are highly correlated $(r=0.90)$ (Westhoff, 2013). The presence of such high correlations indicates that variables do not hold any additional information needed in the analysis (Tabachnick \& Fidell, 2013). As a rule of thumb, if the VIF of a variable is greater than 10, multicollinearity is present. No multicollinearity problems were identified in the present research.

Inferential and multivariate statistics were used to permit the researcher to draw conclusions pertaining to the data. For this research, multiple regression analysis was performed to determine the proportion of variance explained by the independent variables (company performance components) in predicting the dependent variables (CEO remuneration components). The pooled ordinary least square (OLS) regression model was used and assumed that the independent variables were strictly exogenous to the error terms of the model (Gujarati \& Porter, 2009). Further, the multiple regression analyses entered all the independent variables into the equation concurrently. Various regression models were run until an optimum model, with the highest adjusted $R$ square value and $F$-statistic value, was reached. The approach to determine the optimum regression model is an iterative process whereby non-statistical significant independent variables are deleted until the explanatory power does not show an increase and the associated $F$-statistics of the regression do not show a decrease. It is important to note that a regression model can include statistically significant predictors and non-statistically significant predictors, as the aim of a regression is to determine the optimal set of independent variables that optimise the percentage variance explained. Thus, even if some of the measures were not statistically significant, they still contributed to a higher percentage of variance explained, thereby justifying their inclusion.

\section{Results Descriptive statistics}

The target population was South African Schedule 2 SOEs $(N=21)$. After applying the elimination process, a sample of 18 Schedule 2 SOEs was identified as usable for the purpose of the study $(n=18)$. Because there were various instances of significant differences in the descriptive results 
TABLE 3: Chief executive officer fixed pay summary ( $\left.R^{\prime} 000\right)$.

\begin{tabular}{llll}
\hline Year & Mean & Standard deviation & Median \\
\hline 2006 & 1994250.19 & 1052027.05 & 1679000.00 \\
2007 & 2372378.39 & 1242189.05 & 2062141.50 \\
2008 & 2509763.41 & 1325793.61 & 2044607.00 \\
2009 & 2668468.03 & 1203410.04 & 2470000.00 \\
2010 & 2769787.70 & 1034832.47 & 2550500.00 \\
2011 & 3160985.56 & 1394699.82 & 2808500.00 \\
2012 & 3586606.11 & 1243883.04 & 3319964.00 \\
2013 & 3184005.83 & 1459638.89 & 3182000.00 \\
2014 & 3523151.89 & 1487536.39 & 3063420.50 \\
\hline
\end{tabular}

between the means and medians for the $\mathrm{CEO}$ remuneration components and company performance, the researchers reported on the medians. Medians are not affected by outliers compared to means, and generally when data sets have outliers, reporting the median as the central tendency of the data often gives a better 'typical' data value than the mean (Weiers, 2010).

\section{Chief executive officer remuneration components}

Table 3 presents a summary of the descriptive statistics for FP received by CEOs in the 18 SOEs between 2006 and 2014. It is clear that there was an average year-on-year increase of $8 \%$ in FP. Because FP is often determined according to industry market surveys (Murphy, 1999), in most cases FP was not expected to decline during periods of poor financial performance (Kuboya, 2014).

Figure 1 shows a graphical presentation of the descriptive statistics for CEO FP. While the researcher did not consider inflation, it is evident from the graph that the increase in the mean and median fluctuated throughout the period of analysis. From Figure 1 it is evident that CEO FP did not experience the runaway growth claimed in the media. There was a slight increase in the median of FP during 2007, with the highest median of FP being in 2012.

Table 4 contains a summary of the descriptive statistics for TR received by CEOs in the 18 SOEs between 2006 and 2014. Total remuneration experienced an average year-on-year increase of $9 \%$ and a total increase of $93 \%$ over the period.

Figure 2 shows a graphical presentation of the descriptive statistics for CEO TR. From Figure 2 it is clear that TR fluctuated during the period under study. The decrease in TR during the 2009/2010 financial year could have been the fallout from the economic recession, while the decline during the 2012/2013 financial year could be attributed to the great number of acting CEOs during that period across the 18 SOEs.

\section{Company performance measures}

Table 5 presents a summary of the medians (averages) of the descriptive statistics of the company performance components selected for this research study: turnover $(\mathrm{T})$, operating profit $(\mathrm{OP}), \mathrm{NP}, \mathrm{ROCE}, \mathrm{ROE}, \mathrm{LR}$, solvency ratio (SR), AO and IFWE.

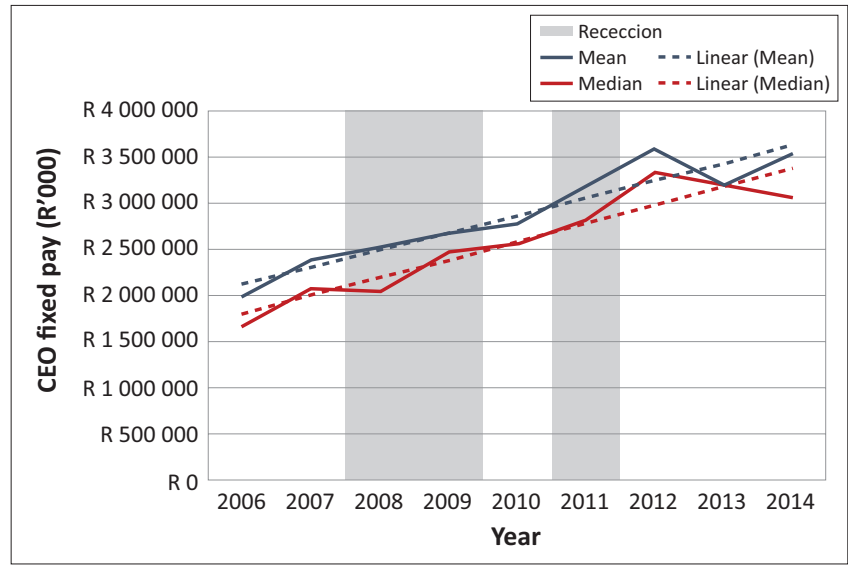

Number of observations in the panel data, $n=162$.

FIGURE 1: Graphical presentation of the descriptive statistics for chief executive officer fixed pay (2006-2014).

TABLE 4: Chief executive officer total remuneration summary ( $\left.\mathrm{R}^{\prime} 000\right)$.

\begin{tabular}{llll}
\hline Year & Mean & Standard deviation & Median \\
\hline 2006 & 3332067.96 & 2265677.94 & 2325750.00 \\
2007 & 3807600.78 & 2136055.98 & 3132787.50 \\
2008 & 4237731.59 & 2744345.78 & 3970035.00 \\
2009 & 4802590.06 & 2716499.95 & 4525037.50 \\
2010 & 4531525.29 & 2300189.77 & 3959000.00 \\
2011 & 4868698.06 & 2666919.72 & 4111500.00 \\
2012 & 5743642.19 & 3174628.91 & 4641500.00 \\
2013 & 4577509.56 & 2634924.46 & 4072000.00 \\
2014 & 5241013.27 & 2695857.11 & 4490227.27 \\
\hline
\end{tabular}

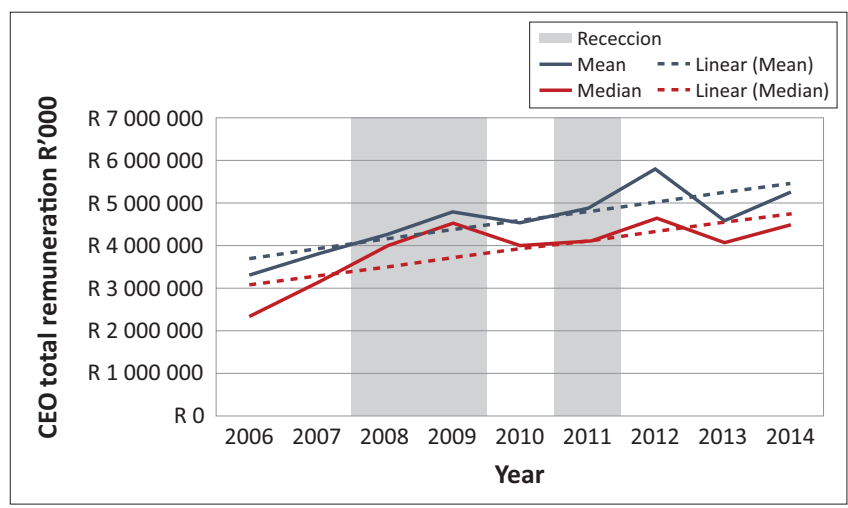

Number of observations in the panel data, $n=162$.

FIGURE 2: Graphical presentation of the descriptive statistics for chief executive officer total remuneration (2006-2014).

Table 6 contains a summary of the standard deviations for the company performance components.

From the descriptive statistics, it is clear that most of the performance measures declined over the 9-year period. The decline in the median measures was as follows: $\mathrm{T}=111 \%$, $\mathrm{OP}=56 \%, \mathrm{NP}=29 \%, \mathrm{ROCE}=74 \%$ and $\mathrm{ROE}=52 \%$. On the other hand, median LR rose by $56 \%$, and SR increased by a mere $2 \%$ over the period.

\section{The relationship between chief executive officer remuneration and company performance}

The objective of this research was to determine the relationship between CEO remuneration (FP and TR) and 
TABLE 5: Company performance measures medians.

\begin{tabular}{|c|c|c|c|c|c|c|c|c|}
\hline Year & Turnover & OP & NP & LR & SR & ROCE & ROE & IFWE \\
\hline 2006 & 2452772500.00 & 610426500.00 & 434574500.00 & 1.36 & 1.70 & 0.13 & 0.12 & 0.00 \\
\hline 2007 & 2935435500.00 & 1093511512.00 & 266969500.00 & 1.25 & 1.94 & 0.14 & 0.12 & 0.00 \\
\hline 2008 & 3373951500.00 & 770996616.00 & 349167000.00 & 1.27 & 1.80 & 0.11 & 0.08 & 0.00 \\
\hline 2009 & 3608791000.00 & 505362500.00 & 254127000.00 & 0.99 & 1.52 & 0.08 & 0.08 & 0.00 \\
\hline 2010 & 3581736500.00 & 407669500.00 & 230156000.00 & 1.15 & 1.48 & 0.06 & 0.04 & 0.00 \\
\hline 2011 & 4122956000.00 & 532792055.50 & 142390500.00 & 1.35 & 1.55 & 0.05 & 0.05 & 121871.50 \\
\hline 2013 & 4882121500.00 & 228674780.00 & 147827000.00 & 1.89 & 1.64 & 0.03 & 0.05 & 4615500.00 \\
\hline 2014 & 5183220000.00 & 267699009.00 & 308056627.50 & 2.24 & 1.74 & 0.03 & 0.06 & 6532500.00 \\
\hline
\end{tabular}

$n=18$

OP, operating profit/loss; NP, net profit/loss; LR, liquidity; SR, solvency; ROCE, return on capital employed; ROE, return on equity; IFWE, irregular, fruitless and wasteful expenditure.

TABLE 6: Company performance measures standard deviation.

\begin{tabular}{|c|c|c|c|c|c|c|c|c|}
\hline Year & Turnovr & OP & NP & LR & SR & ROCE & ROE & IFWE \\
\hline 2006 & 14029089736.97 & 4077494496.67 & 2487634508.85 & 2.39 & 1.25 & 0.27 & 0.60 & 3768925.14 \\
\hline 2007 & 15250858652.69 & 4464230191.10 & 2858114094.06 & 1.99 & 1.33 & 0.26 & 0.33 & 15535439.79 \\
\hline 2008 & 16470407093.20 & 3995448365.57 & 2236625996.73 & 1.82 & 1.37 & 0.21 & 0.23 & 19827142.80 \\
\hline 2009 & 15374995271.63 & 2817253267.84 & 3055558612.50 & 2.61 & 1.90 & 0.69 & 0.32 & 29295525.61 \\
\hline 2010 & 17939019529.13 & 4432694813.84 & 8793504985.39 & 2.19 & 2.09 & 0.17 & 0.39 & 178657442.77 \\
\hline 2011 & 22583327858.44 & 3782249093.03 & 2140105364.53 & 2.45 & 1.68 & 0.11 & 1.17 & 1994354065.92 \\
\hline 2013 & 31093882717.85 & 4617394390.09 & 3313899759.05 & 1.41 & 1.33 & 0.16 & 0.37 & 564377137.34 \\
\hline 2014 & 33731318826.90 & 4036611855.17 & 2399121949.77 & 1.75 & 1.68 & 1.04 & 0.22 & 965285484.85 \\
\hline
\end{tabular}

$n=18$.

OP, operating profit/loss; NP, net profit/loss; LR, liquidity; SR, solvency; ROCE, return on capital employed; ROE, return on equity; IFWE, irregular, fruitless and wasteful expenditure.

the financial performance of South African Schedule 2 SOEs. The results of each of the remuneration components will be discussed in subsequent paragraphs.

\section{Relationship between fixed pay and company performance}

The regression model included 144 balanced panel observations and 18 cross-sectional units over a period of 8 years, because of the inclusion of the AR (1) term. Five iterations were run to determine the optimum final regression model for $\mathrm{FP}$, with the fifth model being regarded as the optimum model. Table 7 provides a summary of each individual regression model (with the $t$-statistics in parentheses).

As can be seen in Table 7, the DW test statistic was 2.5, indicating no serious serial correlation. Model 5 was regarded as the optimum model as the F-statistic increased to 62.54 , in conjunction with an improvement of the adjusted $R^{2}$. The optimum model indicated that $63 \%$ (adjusted $R^{2}=0.63$ ) of the variation in FP was explained by company performance. Table 7 further indicates that audit opinion does not play a role in the determination of FP. It was also noted that the coefficient of NP was negative for all the models tested.

\section{Relationship between total remuneration and company performance}

It is important to note that an amount of R19m TR for one of the SOEs in the year 2008 was omitted from the regression analysis, as it was identified as an outlier that had a significant impact on the fitting of a representative regression model. The regression model included 142 unbalanced panel observations and 18 cross-sectional units over a period of 9 years. Five iterations were run to determine the optimum final regression model for TR. The results of each individual regression model are summarised and presented in Table 8 (with the $t$-statistics in parentheses).

As can be seen from Table 8, the DW test statistic was 2.74, indicating no serious serial correlation. The last regression, Model 5, in Table 8, was regarded as the optimum model, as the $F$-test statistic increased to 43.41 , indicating an optimal fit for the model. Further reduction of independent variables resulted in a decrease in the $F$-statistic and adjusted $R^{2}$ value. The optimum model also explained 64\% (adjusted $R^{2}=0.64$ ) of the variance in TR. The findings from Model 5 indicate that there is a relationship between TR and each of the following components: OP, NP, LR, ROCE and IFWE in South African SOEs.

\section{Discussion}

The primary objective of this research study was to determine whether a relationship existed between CEO remuneration components and company performance within Schedule 2 South African SOEs between 2006 and 2014. Understanding this relationship is important to justify why CEOs receive high remuneration despite the poor performance of SOEs. The expectation was that there would be a negative (or no relationship) between $\mathrm{CEO}$ remuneration components and company performance measures.

Results indicate that the major determinants of FP among company performance measures were turnover, NP and IFWE. However, only the $p$-values of NP and turnover were 
TABLE 7: Regression model: Fixed pay and company performance measures.

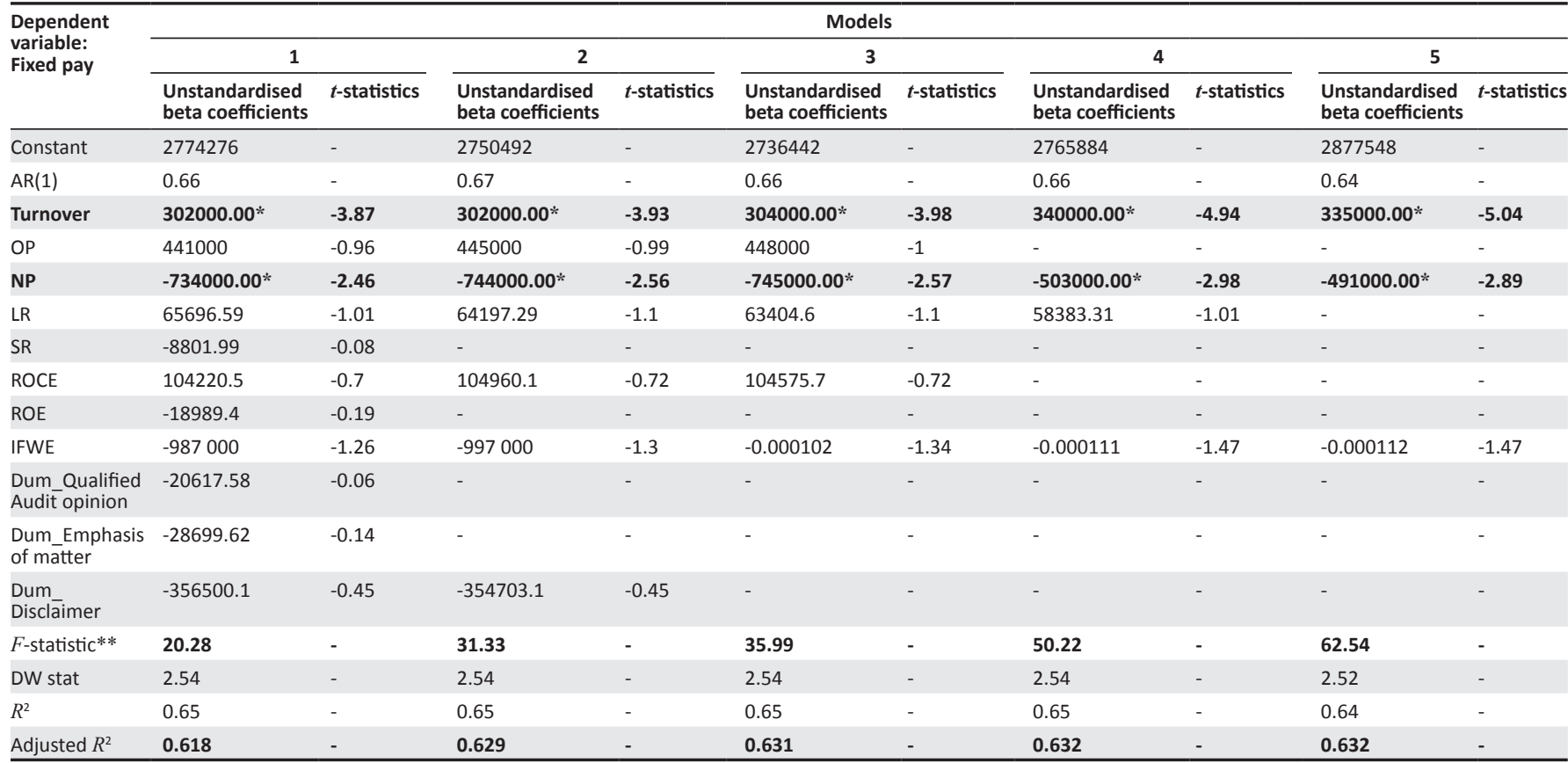

Note: The data set in bold indicate significant values. The $F$-statistics and adjusted $R^{2}$ presented in bold are the important values considered in the analysis.

$n=18$.

$*$, Significance at the $5 \%$ level; **, $p$-value $=0.00$.

DW, Durbin-Watson; OP, operating profit/loss; NP, net profit/loss; LR, liquidity; SR, solvency; ROCE, return on capital employed; ROE, return on equity; IFWE, irregular, fruitless and wasteful expenditure.

TABLE 8: Regression: Total remuneration and company performance measures.

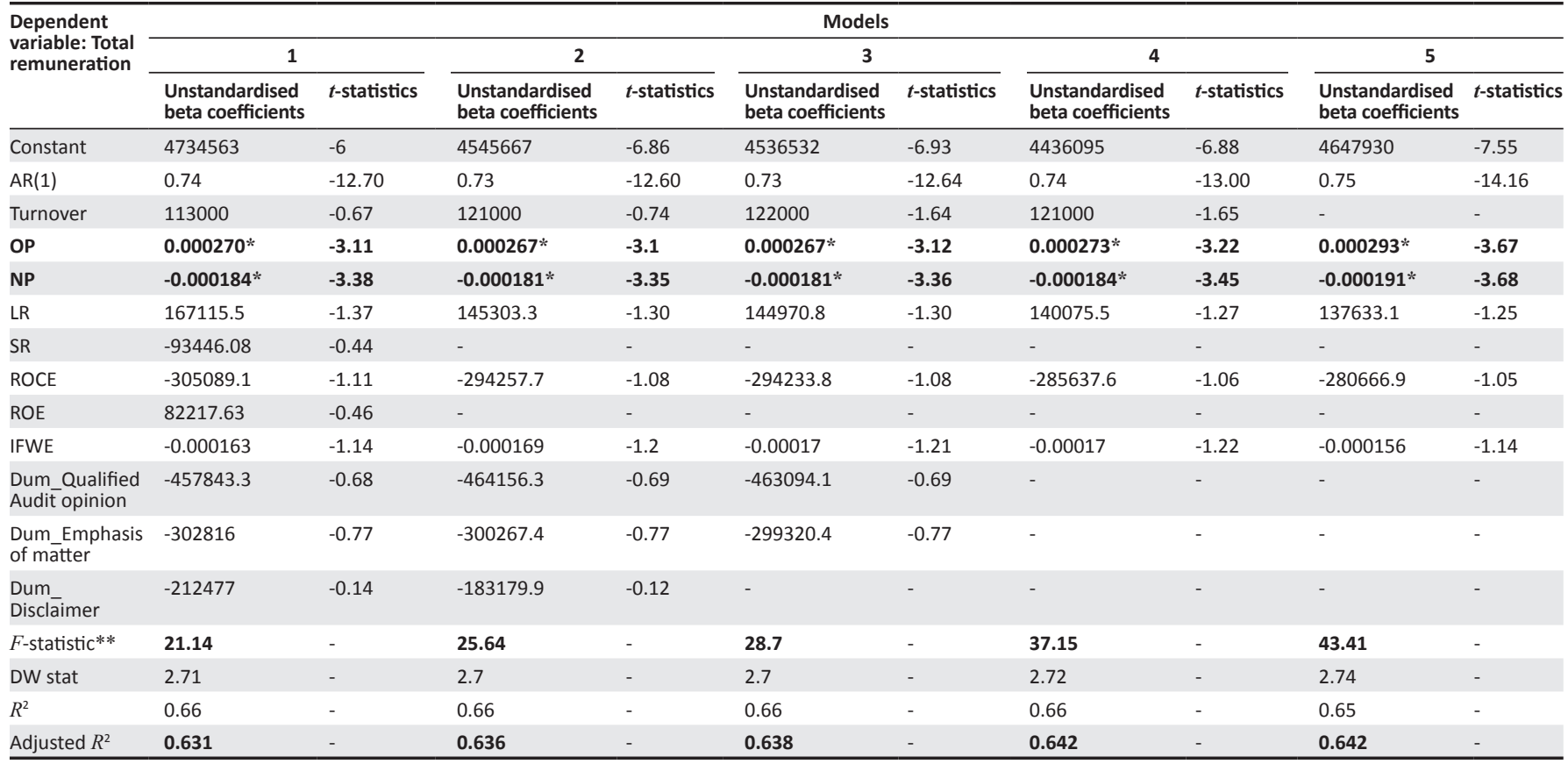

Note: The data set in bold indicate significant values. The $F$-statistics and adjusted $R^{2}$ presented in bold are the important values considered in the analysis.

$*$, Significance at the $5 \%$ level; $* *, p$-value $=0.00$.

DW, Durbin-Watson; OP, operating profit/loss; NP, net profit/loss; LR, liquidity; SR, solvency; ROCE, return on capital employed; ROE, return on equity; IFWE, irregular, fruitless and wasteful expenditure.

statistically significant $(p<0.05)$, suggesting a stronger relationship between FP and these two company performance components. This finding is supported by that of Modau (2013) and Ndofirepi (2015). However, findings from this research are contrary to that of Osei-Bonsu and Lutta (2016), who found that CEOs' salaries are not linked to company performance.
Based on the findings of a statistically strong positive relation between FP and turnover, it could be argued that a CEO who generates a higher income for the SOE is considered to perform well, for which he or she is rewarded. This could explain the connection between CEO remuneration and company performance, as posited by Andersson and Andersson (2006). The negative relationship 
between FP, and NP and IFWE, could suggest that CEOs were paid for poor performance. This could have created a misalignment between what CEOs are being paid and the performance of the SOEs.

The negative relationship of NP and IFWE with FP was expected. A possible explanation for the negative relationship could be that the SOEs' NPs decreased during the study period, and labour costs (such as salaries) increased. The results suggest that for every $\mathrm{R} 1 \mathrm{~m}$ increase in NP, FP decreased by R491 000.00. Turnover was positively significantly linked to FP, suggesting that for every $\mathrm{R} 1 \mathrm{~m}$ increase in turnover, FP increased, on average, by R335000.00. The results further suggest that higher IFWE will result in lower $\mathrm{FP}$, and vice versa.

From the results it is clear that TR had a statistically significant positive relationship with $\mathrm{OP}$, a statistically significant negative relationship with NP, a positive, nonstatistically significant relationship with LR and ROCE, and a negative, non-statistically significant relationship with IFWE. The statistically significant relationship with OP and NP suggests a stronger relationship with TR than the other variables. Findings of a relationship between TR and liquidity are supported by findings by Mbo and Adjasi (2017), who found that SOE performance is positively correlated to liquidity. Tan and Peng (2003), as well as Miller and Leisblein (1996), posited that the positive impact of company liquidity on SOE performance can be attributed to the SOEs' ability to negotiate early payment discounts and take advantage of resourceful procurement as well as negotiating better supplier terms.

The negative relationship between TR and IFWE could suggest that boards and stakeholders reduced TR to penalise SOEs for loss of crucial political connections as posited by Fan, Wong and Zhang (2007). A company's political connections may have both direct and indirect effects on changes in executive remuneration (Conyon \& He, 2016, p. 689).

The findings of this research support the findings of previous studies on executive remuneration that found a relationship between TR and company performance (although those authors conducted these studies in the private sector or in different sectors to that of the present study). For example, Jeppson et al. (2009) found that company revenue was the only statistically significant variable that predicted TR (with an $R^{2}$ of only 0.10). In his study, Modau (2013) found a positive relationship between TR and ROE. Scholtz and Smit (2012) found a strong relationship between TR and turnover. The findings of the present research - that there is a positive relationship with OP - support the findings of Sigler (2011), Nel (2012), Van Blerck (2012) and Modau (2013).

The results regarding the relationship between TR and some of the components of company performance are worrying because of their inverse relationship. This is especially true for NP and ROCE. ROCE is a good indication of the financial performance of SOEs with significant debt. Peyper (2017) reported that nine SOEs had debts of close to R700bn in the 2015/2016 financial year. Because ROCE decreased by 73\% over the 9-year period, the inverse relationship with TR suggests that even though SOEs could not manage their debt and pay back their loans, TR increased.

\section{Practical implications}

From a practical point of view, this research identified certain performance measures that are of importance in determining CEO remuneration. State-owned entity boards and remuneration committees should meticulously consider turnover, OP, NP, liquidity and IFWE when determining CEO remuneration. This study therefore determined specific performance indicators affecting $\mathrm{CEO}$ remuneration in SOEs. By using these performance measures, SOE remuneration committees can determine the relationship between CEO remuneration and company performance based on reliable and statistically defensible measures. Further, by using these measures, SOE management can ensure that the correct measures are used to determine the remuneration components. In addition, the value of this research is that remuneration committees and SOE boards now have empirical evidence to determine CEO remuneration according to performance measures that are positive and significant to Schedule 2 SOEs. If these measures are implemented within SOEs, they could be considered to enhance the Code in King IV.

Based on the research findings, a framework merging financial measures needs to be developed and formalised with a link to SOE objectives. The frameworks, with clear performance measures linked to them, should be effectively monitored under a governance structure.

\section{Limitations and recommendations}

The research was limited to South African Schedule 2 SOEs and therefore excluded all other public entities. The conclusions may therefore not be generalisable to other entities without more research. In addition, this research only investigated the specific relationship between company performance and CEO pay and did not include information on the causal factors influencing CEO remuneration and the financial performance of the organisation. Another limitation could be the use of profitability as a measure of company performance. This is subject to criticism, as executives can manipulate profitability indicators (Attaway, 2000; Ngwenya \& Khumalo, 2012). Therefore, the use of these measures in the present study could have had an effect on the results.

It is recommended that future studies focus on the specific industries within which SOEs operate. This recommendation is based on findings from, for example, Duffhues and Kabir (2008), as well as Goh and Gupta (2010), who found that the type of industry within which a company operates significantly influences the CEOs' remuneration. In addition, the relevance of IFWE in relation to the components of 
CEO remuneration in SOEs was noted. However, there is a paucity of literature that either supports or disagrees with this finding. It is therefore recommended that future studies explore this relationship in more depth. As Conyon (2006) suggested, financial incentives are only one factor motivating executives. Executives are as likely to be motivated by other factors such as intrinsic factors of the job, career concerns, social norms and the like. It is therefore recommended that future studies include these factors in their study.

\section{Conclusion}

In this study, the researchers sought to contribute to the understanding of the relationship between CEO remuneration and the performance of South African SOEs. The results of abundant empirical research examining the relationship are surprisingly inconsistent and, at times, even contradictory.

This research contributes towards filling an important gap in organisational performance literature. It does so from two unique perspectives. Firstly, it introduces an SOE-specific focus to the examination of organisational performance measures. Secondly, it reviews multiple performance variables in determining company performance with emphasis on how the multiple variables are linked.

While the results of the present study suggest that there is a relationship between the CEOs' remuneration and SOEs' performance, the high CEO remuneration despite declining SOE performance during the study period is a concern. Moreover, the evidence of a negative relationship between the CEOs' remuneration and measures of the SOEs' performance suggests that the CEOs' remuneration is not aligned with all of the SOEs' performance measures. This may be a contributing factor with regard to poor performance of South African SOEs.

Even though CEO remuneration may not be excessive, the absence of a link between company performance and the remuneration of CEOs is concerning. The results therefore confirm that dissatisfaction with the CEOs' remuneration may be justified. This indicates that challenges still exist in maintaining a link between company performance and CEO remuneration. Furthermore, the results of this research indicate that there is a need in South Africa to link company performance with CEOs' and executives' pay through adherence to the recommendations of King IV.

Never in the history of South Africa has it been more important to ensure that executive remuneration is aligned to company performance. This is because of the prevailing economic climate, as well as the high levels of unemployment and social unrest. High executive remuneration that is not linked to company performance poses a long-term risk, not only to the continued existence of SOEs, but also to broader society. Until executive remuneration is perceived to be fair and aligned with company performance, it will continue to receive intense criticism from unions, regulators, shareholders and the public.

\section{Acknowledgements}

The authors would like to acknowledge and thank Dr Marthi Pohl for the valuable contribution and assistance with regard to the statistical analysis.

\section{Competing interests}

The authors declare that they have no financial or personal relationships that may have inappropriately influenced them in writing this article.

\section{Authors' contributions}

This research is based on the PhD study of M.L.B., of which M.H.R.B. was the supervisor and M.C. was the co-supervisor. M.L.B. wrote the article and M.H.R.B. and M.C. provided editorial inputs.

\section{References}

21st Century Pay Solutions. (2010). Global reward trends. Johannesburg. Retrieved from https://www.21century.co.za/global-reward-trends/

21st Century Pay Solutions. (2012). Presidential Review Committee on state-owned entities: Strategic management and operational effectiveness ('SOME') work streams of state-owned entities: Development of remuneration practices and policies in SOEs to enable harmonisation amongst SOEs in South Africa. Retrieved from http://www.thepresidency.gov.za/electronicreport/downloads/volume 4/ strategic_management_operational_effectiveness/PRC_Project_Document_ February_2012.pdf

Andersson, C., \& Andersson, J. (2006). Are CEOs paid for performance? Or do they expropriate shareholders wealth? Master's thesis, School of Economics and management, Lund University. Retrieved from http://lup.lub.lu.se/luur/download ?func=downloadFile\&recordOId $=1341526 \&$ fileOId $=2434764$

Attaway, M. C. (2000). A study of the relationship between company performance and CEO compensation. American Business Review, 18(1), 77-85.

Auditor-General South Africa. (2012). Consolidated general report on the national and provincial audit outcomes. PFMA 2012-2013. Retrieved from http://www.agsa. co.za/portals/0/pfma2012-3/2012_13_pfma_consolidated_general_report.pdf

Auditor-General South Africa (AGSA). (2014). Audit terminology: The three aspects we audit. Retrieved from http://www.agsa.co.za/Auditinformation/Auditterminology. aspx

Baptista, M. (2010). CEO compensation and firm performance. Unpublished MSc thesis, HEC, Paris.

Boko, F., \& Yuan Jian, Q. (2011). Failure of state-owned enterprises in Benin. In Management and Service Science, Proceedings of the International Conference, (pp. 1-4). Wuhan: IEEE.

Bradley, S. (2011). Chief executive compensation and the effect on company performance in a South African context. Master of Commerce thesis, Rhodes University.

Bradley, S. (2013). The relationship between CEO compensation and company performance in a South African context. Journal of Economic and Financial Sciences, 6(3), 539-564.

Bussin, M. (2011). The remuneration handbook for Africa: A practical and informative handbook for managing and recognition in Africa. Randburg: Knowres Publishing.

Bussin, M. (2015). CEO pay-performance sensitivity in the South African context. SAJEMS, 18(2), 232-244. https://doi.org/10.4102/sajems.v18i2.838

Bussin, M., \& Blair, C. (2015). Financial indicators of company performance in different industries that affect CEO remuneration in South Africa. SAJEMS, 4, 1-13. https:// doi.org/10.4102/sajems.v18i4.1249

Bussin, M., \& Modau, M. F. (2015). The relationship between chief executive officer remuneration and financial performance in South Africa between 2006 and 2012 SA Journal of Human Resource Management, 13(1), Art. \#668, 1-18. https://doi. SA Journal of Human Resource
org/10/4102/sajhrm.v13i1.668

Bussin, M., \& Nel, M. (2015). Relationship between CEO remuneration and company financial performance in the South African retail and consumer goods sector South African Journal of Human Resource Management, 15(1), 1-11. https://doi. org/10.4102/ac.v15i1.240

Chen, J., Ezzamel, M., \& Cai, Z. (2011). Managerial power theory, tournament theory and executive pay in China. Journal of Corporate Finance, 17(4), 1176-1199. https://doi.org/10.1016/j.jcorpfin.2011.04.008

Conyon, M. (2006). Executive compensation and incentives. Academy of Management Perspectives 25-43. Retrieved from http://www.lse.ac.uk/fmg/ researchProgrammes/corporateFinance/corporateGovernance/pdf/executive CompensationAndIncentives.pdf 
Conyon, M. J., \& He, L. (2016). Executive remuneration and corporate fraud in China. Journal of Business Ethics, 134(4), 669-691. https://doi.org/10.1007/s10551-0142390-6

Corporate Governance of State-Owned Enterprises in Africa. (2009). Retrieved from http://www.oecd.org/daf/ca/corporategovernanceofstate-ownedenterprises/ 42713426.pdf

Crafford, D. (2012). SOE remuneration and wage gap analysis. Position paper prepared for the Presidential SOE Review Committee. Retrieved from http://www. thepresidency.gov.za/electronicreport/downloads/volume_3/strategic management_operationala_effectiveness/Remuneration_policies_of_SOEs_ taking_into_account_wage.doc

Dai, Y. (2014). Research on influencing factors of executive compensation in China's monopoly industries. Open Journal of Business and Management, 2(3), 210-218. https://doi.org/10.4236/ojbm.2014.23026

Demirer, I., \& Yuan, J. J. (2013). Executive compensation structure and firm performance in the U.S. restaurant industry: An agency theory approach. Journa of Foodservice Business Research, 15(5), 421-438.

Duffhues, P., \& Kabir, R. (2008). Is the pay-performance relationship always positive? Evidence from the Netherlands. Journal of Multinational Financial Management, 18, 45-60. Retrieved from http://www:Elsevier.com/locate/econbase

Ellig, B. R. (2007). The complete guide to executive compensation. New York, NY: McGraw-Hill.

Fan, J., Wong, T. J., \& Zhang, T. (2007). Politically connected CEOs, corporate governance, and post-IPO performance of China's newly partially privatized firms. Journal of Financial Economics, 84, 330-357. https://doi.org/10.1016/j.jfineco. 2006.03.008

Florin, B., Hallock, K. F., \& Webber, D. (2010). Executive pay and firm performance: Methodological considerations and future directions. Conrnell University, ILR School. Retrieved from http://digitalcommons.ilr.cornell.edu/cgi/viewcontent. cgi?article $=1014 \&$ context $=$ cri

Fripp, C. (2015, June 25). Eskom to receive R23 billion-government bailout. Htxt. africa. Retrieved from http://www.htxt.co.za/2015/06/25/eskom-to-receive-r23billion-government-bailout/

Gerber, J. (2016, September 30). SAA's financials for 2016 show a 'pleasing' R1.5bn loss. City Press. Retrieved from http://city-press.news24.com/News/saasfinancials-for-2016-show-a-pleasing-r15bn-loss-20160930

Gigliotti, M. (2012). The compensation of top managers and the performance of Italian firms. The International Journal of Human Resource Management, 889907. https://doi.org/10.1080/09585192.2012.702317

Goh, L., \& Gupta, A. (2010). Executive compensation, compensation consultants, and shopping for opinion: Evidence from the United Kingdom. Journal of Accounting, AuditingandFinance, 25,607-643.https://doi.org/10.1177/0148558X1002500407

Gujarati, D. N., \& Porter, D. C. (2009). Basic econometrics (5th edn.). New York, NY: McGraw-Hill International Edition.

He, C. J., Conyon, M. J., \& Shaw, T. S. (2013). Informativeness of performance measures and Chinese executive compensation measures and Chinese executive doi.org/10.1007/s10490-013-9353-9

Henderson, K. J. (2014). What are the 4 types of audit reports? Retrieved from http:// smallbusiness.chron.com/4-types-audit-reports-3794.html

International Standard on Auditing 706 (Revised). (2016). Emphasis of matter paragraph and other matter paragraphs in the independent auditor's report. Retrieved from https://webcache.googleusercontent.com/search?q=cache:FmJsnEZEI3UJ:https:// www.irba.co.za/upload/ISA-706-Revised.pdf $\& c d=1 \& h|=e n \& c t=c| n k \& g l=z a$

Jensen, M. C., \& Murphy, K. J. (1990). Performance pay and top management incentives. Journal of Political Economy, 98(2), 225-264. https://doi.org/10.1086/ 261677

Jensen, M. C., \& Murphy, K. J. (2004). Remuneration: Where we've been, how we got to here, what are the problems, and how to fix them. Finance Working Paper No, 44/2004. Retrieved from http://www.nccr-finrisk.uzh.ch/media/pdf/jensenpaper.pdf

Jeppson, C. T., Smith, W. W., \& Stone, R. S. (2009). CEO compensation and firm performance: Is there any relationship? Journal of Business \& Economics Research, 7(11), 81-93.

Jerry, C., Pan, X., \& Tian, G. (2011). Disproportional ownership structure and payperformance relationship. China Journal of Corporate Finance, 17(3), 541-554. https://doi.org/10.1016/j.jcorpfin.2011.02.006

Kato, T., \& Long, C. (2006). Corporate Governance in China: Evidence from firms listed in Shanghai and Shenzhen stock exchanges. Economic Development and Cultural Change, 54(4), 945-983. https://doi.org/10.1086/503583

Krauter, E., \& De Sousa, A. F. (2013). Executive compensation and corporate financial performance: Empirical evidences on Brazilian industrial companies. Journal of Modern Accounting and Auditing, 9(5), 650-661.

Kuboya, D. (2014). A critical analysis of executive remuneration and company performance for South African listed companies. Unpublished Master's of Business Administration thesis, University of Stellenbosch.

Kyalo, B. M. (2015). Relationship between executive compensation and financial performance of commercial state-owned enterprises in the energy sector in Kenya. Unpublished MBA research report. School of Business, University of Nairobi, Kenya. Retrieved from http://erepository.uonbi.ac.ke/bitstream/handle/11295/ $94500 /$ Kyalo_Relationship\%20between $\% 20$ executive $\% 20$ compensation. pdf?sequence $=1$ \&isAllowed $=y$

Lippert, R. L., \& Porter, G. (1997). Understanding CEO pay: A test of two pay-toperformance sensitivity measures with alternative measures of alignment and influence. Journal of Business research, 40(2), 127-138. https://doi. org.10.1016.2963(96)00283-4
Majangaza, S. (2015, April 29). SAA CEO settles for R2.7m pay-out. Dispatch live. Retrieved from http://www.dispatchlive.co.za/business/2015/04/29/saa-ceosettles-for-r2-7m-payout/

Maloa, F. (2015). Transformation as an element of executive remuneration in South African state-owned entities. Problems and Perspectives in Management, 13(4), 43-52. Retrieved from https://businessperspectives.org/journals_free/ppm/ 2015/PPM_2015_04_Maloa.pdf

Maloa, F., \& Bussin, M. (2016). Determinants of executive compensation in South African state-owned enterprises. South African Journal of Labour Relations, 40(1), 8-24.

Mbo, M., \& Adjasi, M. J. (2014). Drivers of organisational performance: A state-owned enterprise's perspective. The Biennial Convergence of the Economic Society of South Africa. University of the Free State, Bloemfontein, South Africa.

Mbo, M., \& Adjasi, C. (2017). Drivers of organizational performance in state-owned enterprises. International Journal of Productivity and Performance Management, 66(3), 405-423. https://doi.org/10.1108/IJPPM-11-2015-0177

Miller, K. D., \& Leisblein, M. J. (1996). Corporate risk-return relations: Returns variability versus downside risk. Academy of Management Journal, 39(1), 91-122. https://doi.org/10.2307/256632

Minhat, M., \& Abdullah, M. (2014). Executive compensation in government-linked companies: Evidence from Malaysia. Applied Economics, 46(16), 1861-1872. https://doi.org/10.1080/00036846.2014.887192

Modau, M. F. (2013). The relationship between chief executive officer (CEO) remuneration and financial performance of an organisation. Unpublished MBA thesis, Gordon Institute of Business Science, University of Pretoria.

Murphy, K. J. (1985). Corporate performance and managerial remuneration: An empirical analysis. Journal of Accounting and Economics, 7(1), 11-42. https://doi. org.1016-4101(85)90026-6

Murphy, K. J. (1999). Executive compensation. In O. C. Ashenfelter \& D. Card (Eds.), Handbook of labor economics (pp. 2485-2536). Part B. Elsevier. Retrieved from http://www.sciencedirect.com/science/article/pii/S15744699300249

National Treasury. (2015). Public institutions listed in PFMA schedule 1, 2, 3A, 3B, 3C and 3D. Retrieved April 30, 2015, from http://www.treasury.gov.za/legislation/pfma/ public\%20entities/2015-04-30\%20Public\%20institutions\%20Sch\%201-3D.pdf

Ndofirepi, T. P. (2015). The relationship between CEO compensation and various performance indicators in South Africa. Unpublished Master's dissertation, University of the Witwatersrand, South Africa.

$\mathrm{Nel}, \mathrm{M}$. (2012). Sensitivity of guaranteed cost to company of CEOs in the South African retail and consumer goods sector. Unpublished Master's dissertation, Gordon Institute of Business Science, University of Pretoria, Pretoria.

Ngwenya, S., \& Khumalo, M. (2012). CEO compensation and performance of stateowned enterprises in South Africa. Corporate Ownership and Control, 10(1A), 97-109. https://doi.org/10.22495/cocv10i1art9

Nourayi, M. M., \& Mintz, M. (2008). Tenure, firm's performance, and CEO's compensation. Managerial Finance, 34(8), 524-536. https://doi.org/10.1108/030 74350810874055

Osei-Bonsu, N., \& Lutta, J. G. M. (2016). CEO cash compensation and firm performance: An empirical study from emerging markets. Business and Economic Research, 6(2), 79-99. Retrieved from http://www.macrothink.org/ber

Otieno, D. O. A. (2011). The relationship between financial performance and executive remuneration in South African state-owned enterprises: An agency theory perspective. Unpublished MCom minor dissertation. University of Johannesburg, Johannesburg.

Ozkan, N. (2011). CEO compensation and firm performance: An empirical investigation of UK panel data. European Financial Management, 17(2), 260-285. https://doi org/10.1111/j.1468-036X.2009.00511.X

Papenfuss, U., \& Schmidt, C. (2016). Pay-performance relationship in German stateowned enterprises: Evidence and reflection for organizational success research with undistorted and 'Right' data. Corporate Ownership \& Control, 13(2), 336 350. https://doi.org/10.22495/cocv13i2cLp3

Peyper, L. (2016, October 21). No raise on top of Eskom boss Brian Molefe's R9.4m salary. Fin24. Retrieved from http://www.fin24.com/Economy/Eskom/no-raiseon-top-of-eskom-boss-brian-molefes-r94m-salary-20161021

Peyper, L. (2017, June 07). Gigaba: (9 SOEs have debt of close to R700bn. Fin24. Retrieved from http://www.fin24.com/Economy/gigaba-9-soes-have-debt-ofclose-to-r700bn-20170607

Polakow, D. A. (2015). If a portfolio manager who cannot count fields as a four-leaf clover, is he still lucky? Investment Analysts Journal, 39(72), 53-71.

Public Finance Management Act 1. (1999). Retrieved from http://www.treasury.gov. za/legislation/PFMA/act.pdf

Rothpletz, P. (2017, July 01). Treasury announces SAA bailout to settle R2.3bn debt. Mail \& Guardian. Retrieved from https://mg.co.za/article/2017-07-01-saareceives-r23bn-bailout

Scholtz, H. E., \& Smit, A. (2012). Executive remuneration and company performance for South African companies listed on the Alternative Exchange (AltX). Southern African Business Review, 16(1), 22-38.

Sigler, K. J. (2011). CEO compensation and company performance. Business and Economics Journal, BEJ-31. Retrieved from http://astonjournals.com/manuscripts/ Vol2011/BEJ-31_Vol2011.pdf

South African Qualifications Authority. (2013). Policy on avoidance of irregular, unauthorised, fruitless and wasteful expenditure. Retrieved from http://www. saqa.org.za/docs/pol/2014/FPG\%2003\%20Avoidance\%20of\%20irregular,\%20 saqa.org.za/docs/pol/2014/FPG\%2003\%20Avoidance\%20f\%20irregular, $\% 20$ unauthorised,\%2013-12-04.pdf 
Swatdikun, T. (2013). Executive pay-performance sensitivity and its consequences: Empirical evidence on the role of ownership in Thailand. Unpublished Doctor of Empirical evidence on the role of ownership in Thailand. Unpublished
Philosophy thesis, University of Southampton, School of Management.

Tabachnick, B. G., \& Fidell, L. S. (2013). Using multivariate statistics (6th edn.). Boston, MA: Pearson.

Tan, J. \& Peng, M. W. (2003). Organizational slack and firm performance during economic transitions: Two studies from an emerging economy. Strategic Management Journal, 24, 1249-1263. https://doi.org/10.1002/smj.351

Tariq, U. (2010). CEO compensation: Relationship with performance and influence of board of directors. Unpublished Master's thesis, Gotland University, Sweden.

Theku, M. (2014). CEO compensation sensitivity to performance in the South African mining industry. Unpublished Master's dissertation, Gordon Institute of Business Science, University of Pretoria.

Theunissen, P. (2010). Is executive remuneration out of control? Computus, Bethlehem. Retrieved from http://www.computus.co.za/Publikasies/ CEOVReportPDF.pdf

Tian, Y. S. (2013). Ironing out the kinks in executive compensation: Linking incentive pay to average stock prices. Journal of Banking and Finance, 37, 415-432. https:// doi.org/10.1016/j.jbankfin.2012.09.025
Van Blerck, T. G. (2012). The relationship between executive remuneration at financia institutions and economic value added. Unpublished Master's of Business Administration thesis, Gordon Institute of Business Science, University of Pretoria.

Walker, D. I. (2010). The law and economics of executive compensation: Theory and evidence. Boston University School of Law Working Paper No. 10-32, pp. 1-23. Retrieved from http://www.bu.edu/law/workingpapers-archive/documents/ walkerd100610.pdf

Weiers, R. M. (2010). Introduction to business statistics (7th edn.). Mason, IA: SouthWestern Cengage Learning.

Westhoff, F. (2013). An introduction to econometrics. Cambridge, MA: Massachusetts Institute of Technology.

Williams, J. R., Haka, S. F., Bettner, M. S., \& Carcello, J. V. (2006). Financial accounting (12th edn.). New York, NY: McGraw-Hill International Edition.

Xin, Q. Q. \& Tan, W. O. (2009). Market-oriented reform, firm performance and executive compensation in Chinese state-owned enterprises, Economic Research Journal, 11, 99-108.

Zigler, K. J. (2011). CEO compensation and company performance. Business and Economics Journal, BEJ-31, 1-8. Retrieved from http://astonjournals.com/ manuscripts/Vol2011/BEJ-31_Vol2011.pdf 